Journal of Money and Economy

Vol. 16, No. 1, Winter 2021

pp. 71-92

DOI: $10.29252 /$ jme.16.1.71

Original Research Article

\title{
Investigating the Effect of Structural Changes and Trade Liberalization on Total Factor Productivity in Iran (1991-2018)
}

\author{
Yasaman Hokmollahi* \\ Ali Souri ${ }^{\ddagger}$ \\ Ali Taiebnia ${ }^{\dagger}$
}

Received: 25 Jan 2021

Approved: 07 Jul 2021

Structural change plays an important role in developing any economy, so understanding it is critical to make policies that increase total factor productivity. The structural change that leads to an efficient resource allocation after trade reforms is desirable; the key factor that can affect the relation of "structural change and trade liberalization" with productivity is the quality of institutions. In this study, we first use the principal component method to propose a multidimensional index for structural change and then apply the ARDL econometrics model to evaluate the effect of trade liberalization and structural changes on total factor productivity in Iran during 1991- 2018. The results show that structural changes increase the total factor productivity, and trade liberalization has a positive and significant effect on total factor productivity in the short term. Our results also indicate that there is no long-run relationship in this period.

Keywords: Structural change, Trade liberalization, Institutions, Productivity

JEL Classification: C5, F16, R2

\section{Introduction}

One of the first and most central views in economic development texts is that development requires structural changes. Based on the historical experience of industrialized countries and the trend of newly industrialized countries in recent decades, structural changes in industrialization and traditional growth factors (labor and capital) are potential factors for economic growth. A key factor in distinguishing successful countries from unsuccessful ones is the

\footnotetext{
${ }^{*}$ Faculty of Economics - Alborz Campus, University of Tehran Tehran, Iran;

Yasmin.hokmollahi@ut.ac.ir

$†$ Faculty of Economics, University of Tehran, Tehran, Iran; taiebnia@ut.ac.ir (Corresponding Author)

$\$$ Faculty of Economics, University of Tehran, Tehran, Iran; alisouri@ut.ac.ir
} 
speed at which these structural changes occur. Countries can get out of poverty and get richer by producing a variety, that is, not limited to agricultural products and other traditional products. Simultaneously, if labor and other resources are shifted from the agricultural sector to modern economic activities, overall productivity and incomes increase (McMillan and Rodrik, 2011).

Structural change is one of the focuses of development policy. Understanding the structure of the economy and designing appropriate policies that pave the way for the growth and promotion of structural change is what countries need today. Thus, the multidimensional measurement of structural change, called the structural change index, measures the rate of structural change in economies and shows different structural change aspects. The Structural Change Index (STI) contributes to policy-making, infrastructure investment decisions, and political commitment to accelerate the transition from poverty to inclusive growth, and benefits are shared equally among citizens in each country (Kelbore, 2014).

Successful structural change requires the optimal use of factors in which adjustment costs for macroeconomics are minimized. The nature, speed, and cost of adjustment vary for developed and developing economies, which is affected by the quality of institutions. Structural change to higher-productivity sectors suggests that resource reallocation does not always increase productivity and is influenced by factors such as institutional barriers to access to modern sectors (John, 2016).

On the other hand, foreign trade modifies inefficiency in the market by creating competition and reduces the production of lower quality goods and higher costs, so domestic producers make more efforts to improve the level of technology they use to maintain and increase their competitiveness in domestic and foreign markets (Herzer, 2005). Efficient resource allocation and increased productivity increase countries' competitiveness, and economists believe that increasing the level of competitiveness by increasing productivity is better and more effective than competitiveness from cheap primary resources. Firms and countries that have become competitive through the low cost of raw materials face lower production methods (higher efficiency) or more advanced technology (Choudhri and Hakura, 2000). The first fundamental step in discussing this is to understand the impact of trade on employment adjustment, so complementary policies that affect trade policy should be considered. Complementary policies, such as effective institutional and regulatory reforms, allow economies to be flexible and adapt appropriately to changing economic environments. Such policies can reduce 
the time it takes for the adjustment process to occur, as well as the adjustment costs associated with increasing trade liberalization. It, in turn, can ensure that the desired profit from the trade is maximized. The current paper, taking into account the importance of the effect of trade liberalization and structural changes on the productivity of all factors, is organized as follows: In the next section, we review the theoretical foundations and the literature and then extract the structural change index and estimate the model. Section three and four include literature review and model specification, respectively. Also, model estimation results as well as conclusions are presented in section five and six.

\section{Theoretical Foundations}

A structure is a network of connections between a system's components and determines the structure, nature, and function of all. The economy is made up of interconnected sectors. How the sectors relate and the share of each sector determine the structure of the economy. Structural change refers to a change in the economy structure that typically leads to an increase in the relative share of production and services, but on a broader scale, structural change also includes social, political, and cultural changes. The rate of structural change varies from country to country and has far-reaching economic consequences. The high degree of openness of the economy and the expansion of trade lead to restructuring, constant technological changes, and a dramatic increase in industrialization, which increases the skills and wage gap between skilled and unskilled workers (Aizenman et al., 2012).

Modern analysis of structural change originates from Fischer (2003) and Clark (1940) and deals with changes in the share of the labor force employed in each sector (Syrquin, 1988). In later years, studies by Kuznets shed light on the complexities of structural change. The indisputable facts that pay attention to the economic aspect of structural change are classified into two criteria of structural change, namely production and consumption. Both criteria are equally important; the current paper addresses the production criteria.

The production criterion analyzes employment developments and the share of value-added in each sector's GDP as a structural change. That is, structural changes occur when an increase in per capita GDP is accompanied by a decrease in employment share and the share of nominal value added of the agricultural sector; also increase the share of employment and the share of nominal value-added of the services and industry sector. Kelbore (2014), using Kuznets (1971) and Timmer and Akkus (2008), takes a broader framework in the analysis of structural change and provides a 
multidimensional index of structural change that includes economic, social, and political dimensions. The defined framework takes into account a wide range of structural changes with the following as its basis:

A. Derived from the criterion of production, interprets changes in the composition of parts as a sign of structural change. Accordingly, it considers the share of value-added of each sector in GDP and compares the observed changes in the composition of sectors. Another important aspect of structural change in the standard of production is the change in employment share among sectors.

B. Considers social and demographic indices as a measure of structural change; Social and demographic dimensions are indicated by the rate of urbanization, population transfer, and human capital accumulation. The main reason for these measures is that historical evidence shows that high per capita income growth in the developed world has been accompanied by rapid changes in production and social structure (Chenery et al., 1988). Industrialization or urbanization is accompanied by a change in demographic patterns, a high increase in human capital through formal education, and a change in a set of values that largely corresponds to the opportunities and requirements associated with modern urban life. Kelbore sees urbanization as the result of structural change and takes it as one of the dimensions to measure the extent of structural change in economies. Population transfer from high birth rate / high mortality to low birth rate / low mortality is also considered as one of the cases (Kelbore, 2014).

Theoretically, there are different arguments about the importance of the impact of structural change on the productivity of total factors, which can be summarized as follows:

1) The economy is divided into several sectors. Since the efficiency of factors varies in sectors, the redistribution of resources to higher productivity sectors increases total productivity. One of the main studies in this field is Lewis's (1954) dual economy models. Productivity growth that occurs due to the redistribution of labor in the sectors may result from various factors; for example, people who move to more productive sectors to earn higher wages. This shift may also be due to a change in the demand paradigm for products in different sectors. Labor demand elasticity describes how structural changes affect productivity - such as the productive sector, which absorbs surplus labor from the agricultural sector (Lewis, 1954; Harris and Todaro, 1970). An unemployed worker who replaces their old job with a higher-productivity job leaves a positive effect on increasing economic growth. However, if this worker moves to 
a lower-productivity sector, this redistribution of labor leads to a reduction in total productivity and does not promote economic growth (McMillan and Rodrik, 2011).

2) Substitution of capital for labor in the production process, or in other words, capital intensive, increases the share of capital goods and more efficient use of the data of the production process and natural resources. It changes the structure of production.

3) Most economists believe that specialization is the basis of higher levels of income and productivity, provided that the specialization in these countries is in dynamic industries and markets. The rate of productivity is higher in countries with more specialized industries (Rahimi Boroujerdi, 2010).

4) For many economists, industrialization plays a key role in the growth process. In this view, the modern industrial sector's development has a very high contribution to the dynamics of total production growth due to the high growth of productivity of that sector, economies of scale, innovation, and on-service learning. Most developed and newly industrialized countries have been able to achieve a desirable level of economic growth and development by adopting a strategy of industrialization and special policies such as import substitution or export development (Moshiri and Eltejae, 2015).

5) According to the norm structure hypothesis, if each income level creates a specific industrial structure, an income-dependent norm structure can be hypothesized. It is expected that countries that exhibit this norm structure, or in other words, have a natural and income-level structure, will be able to grow faster, but countries that do not have a natural or income-level structure, i.e., deviated from the norm structures, will grow more slowly (Aiginger, 2001). The norm structure hypothesis is very important in crude oil-exporting countries where high oil revenues have increased their per capita income level. The forthcoming sector increases growth through its connections with other sectors of the economy; however, in crude oilexporting countries, the impact of oil revenues on the economy is much greater than this sector's links with other sectors of the economy. The existing literature on the theory of single-product growth has examples of rapid growth based on the exploitation of natural resources, which, despite rising incomes, has not led to continuous development and structural change at the appropriate pace (Syrquin, 1998).

In this study, 11 variables have been selected as structural variables to define the multidimensional index of structural changes, using the works of 
Kuznets (1971), Chenery (1988), and Kelbore (2014). In this selection, an attempt has been made to examine the most important aspects of structural change in terms of national production structure based on different sectors of the economy, labor allocation in different sectors, foreign trade structure, and demographic variables. These variables are introduced in the table below. We obtain a multidimensional index of structural changes using the principal component method.

Table 1

Variables in the Multidimensional Index

\begin{tabular}{|c|c|c|c|}
\hline $\begin{array}{l}\text { Production } \\
\text { structure }\end{array}$ & Labor allocation & $\begin{array}{l}\text { foreign trade } \\
\text { structure }\end{array}$ & $\begin{array}{l}\text { demographic } \\
\text { variables }\end{array}$ \\
\hline $\begin{array}{l}\text { - the nominal value- } \\
\text { added share in } \\
\text { services } \\
\text { - the nominal value- } \\
\text { added share in the } \\
\text { industry } \\
\text { - the nominal value- } \\
\text { added share in } \\
\text { agriculture }\end{array}$ & $\begin{array}{l}\text { - employment } \\
\text { Share in services } \\
\text { - employment } \\
\text { Share in industry } \\
\text { - employment } \\
\text { Share in agriculture }\end{array}$ & $\begin{array}{l}\text { - total exports to } \\
\text { GDP } \\
\text { - total imports to } \\
\text { GDP }\end{array}$ & $\begin{array}{l}\text { - Urbanization rate } \\
\text { - Birth rate } \\
\text { - Mortality rate }\end{array}$ \\
\hline
\end{tabular}

On the other hand, understanding the effect of trade liberalization on overall productivity is important. Trade liberalization is the move towards free trade through the reduction of tariffs and trade barriers. In the practical definition of trade liberalization, it is generally assumed that a trade regime is liberalized if the amount and type of support in that regime have decreased. It is also possible that the change in the form of support will be considered a step towards trade liberalization (Rahimi Boroujerdi, 2010).

In general, the advantages of foreign trade leading to improved productivity of the factors of production can be classified as follows:

a. Creating competition,

b. Increasing efficiency,

c. efficient allocation of resources,

d. Ability to use economies of scale,

e. Expanding domestic markets,

f. Expanding initiative and innovation,

g. Spread of technology.

Also, the disadvantages of foreign trade are as follows:

a. Costs of structural changes, 
b. Increasing gap between countries and inequality,

c. Increasing international risks,

d. Possibility of observing Dutch disease (Rahimi Boroujerdi, 2010)

Foreign trade-based growth theories emphasize that foreign trade improves overall productivity. By improving resource allocation, access to better technology and intermediate goods, utilizing economies of scale, increasing domestic competition and creating a conducive environment for innovation. There are mechanisms through which the expansion of international trade can facilitate technology transfer: 1. Contact with foreign agents through exports can lead to faster transfer of foreign technical knowledge. 2. More access to foreign products through imports makes it possible to imitate in the country. Both of these mechanisms mean that technology transfer and thus the productivity of the factors of production in one sector depends to a large extent on the volume of foreign trade within that sector. It is also possible for trade in one sector to increase productivity in another through output and input relationships. Studies show that the impact of trade on improving productivity in different sectors depends on that sector's technical complexity.

In the traditional sectors of low-growth production, the effect of increased international trade on productivity is very small. But in high-growth sectors, increased foreign trade has a large effect on productivity. Therefore, it can be concluded that increasing international trade by increasing import competition or expanding exports in high-growth sectors is an important source for technology transfer to medium- and low-growth sectors and thus increasing productivity in these sectors (Rahimi Boroujerdi, 2006).

As mentioned, foreign trade shifts the allocation of resources from lowproductivity sectors and industries to high-productivity industries (restructuring), thereby increasing overall productivity and economic growth. Particularly in the labor market, the relationship between workers' ability to change jobs domestically or between sectors and industries, as well as the costs associated with this shift, in response to changes in the international economy, is being considered by politicians, academics, and the public. It is mainly due to the presence of adjustment costs when reallocating resources as a result of increased competition due to increased openness. Resource adjustment can be within or between industries, and therefore associated costs may vary. Adjustment costs can be created in a perfect competition market where prices are flexible. If factors are affected by any heterogeneity and product nature, redistribution through trade can transfer resources. Production in the adjustment period may be lower than the previous production level, which is due to the workforce's training and adaptation to the current situation. 
Adjustments can also occur where the market is not perfect competition, such as in a situation where the minimum wage is set. In this example, trade costs can outweigh trade benefits, and trade liberalization can be a Pareto inferior (Lindley et al., 2005).

In addition, adjustment evidence, commonly found in developing countries, shows that restructuring in a closed economy is less than structural change when the economy opens to international trade. Trade openness means increased exposure to external risks and consequently greater demand for social insurance. Increased openness will lead to the closure of enterprises and the loss of jobs in some industries and sectors, while it may also create opportunities in some jobs. After trade liberalization, resources such as labor and land may become obsolete or need training or reorganization. It is difficult for developing countries to divert their resources to more productive activities that minimize these economies' dysfunction. Ideally, post-liberalization structural change will allow resources to be transferred to high-productivity activities, thus enabling sustainable growth and improved living standards. However, restructuring policies such as trade liberalization have different results due to the undesirable costs associated with restructuring policies, such as the costs of jobs lost through trade reform, as well as the comparative advantage developing countries in traditional sectors with low skills, technology, and growth potential. Thus, free trade can encourage expertise in these areas and limit productivity growth, widening the gap between rich and poor countries (Choudhri and Hakura, 2000).

The presence of higher quality institutions can contribute to the desired economic policy achievements, including trade liberalization. For some countries, effective institutions' presence means an increasing structural change in growth as resources become more freely and efficiently reallocated. On the other hand, for countries with weak institutions, industries may not respond well to trade liberalization policies.

Given the potential of complementary policies to influence trade policy outcomes, it is important to consider the effects of such complementary policies. Complementary policies, such as effective institutional and regulatory reforms, allow economies to be resilient and adapt appropriately to changing economic environments, such as those caused by exposure to external shocks from freer trade. Such policies can reduce the time it takes for the adjustment process to take place, as well as the adjustment costs associated with increasing trade liberalization. In this case, the maximum profit from the trade is expected. For example, if prices are inflexible, signal transmission to buyers and sellers will be limited, and this may prevent resources from shifting 
to higher-productivity activities. Institutions reduce uncertainties caused by incomplete information about the behavior of other people in the interaction process. As a result, it reduces the cost of adjustment. Institutions facilitate the guidance of information about market conditions, commodities, and participants, thereby facilitating collaboration between market players (John, 2016).

\section{Literature Review}

Historically, Kuznets's empirical research in the 1950s and 1960s on the role of structural changes in economic growth is of great importance. For the countries that began modern economic growth from the late 18th century to the late 19th century, Kuznets revealed a historical correlation between high per capita growth rates and productivity and the magnitude of the production structure's transformation. In his studies, Kuznets points out that the combination of the important components of demand, production, employment, the external sector of the economy, and demographic variables determines the economy's shape and structure. Kuznets introduces the share of economic sectors as one of the important variables of economic structure. According to him, increasing the share of industries in GDP and, accordingly, reducing the share of the agricultural sector in terms of GDP is one of the documented realities in the growth process (Chenery et al., 1988).

Syrquin (1986) examined the relationship between GDP growth and the economy structure, including the structure of production and trade, for 19 Latin American countries from 1960 to 1982. According to some results, there is a significant positive relationship between export growth rate variables, export share and investment share of GDP with economic growth. He considers the increase in the share of industrial exports in total exports as one of the signs of the economy's industrialization. Today, the close relationship between economic growth and exports of each country is confirmed.

In 1988, Chenery published a book entitled "Patterns of Development" in which 101 non-socialist countries were studied from the perspective of structural change. In 1988, Chenery et al. repeated the study with 108 countries and obtained the same results. They concluded that as per capita income increases, the share of the primary sector (agriculture and mining) decreases, both in terms of value-added and the share of total labor, with the increases in the share of industry and services. Unlike that of Lewis and developmental stage patterns, development patterns, while they see growing savings and investment as necessary for development, do not see it as sufficient for economic growth. In development models, in addition to the 
accumulation of physical and human capital, a set of related changes in the socio-economic structure is necessary to make the transition from the traditional to the modern system. Structural changes in all economic functions include changes in production and changes in the composition of consumer demand, foreign trade and the use of primary resources, changes in socioeconomic factors such as urbanization, and the growth and distribution of a country's population.

McMillan and Rodrik (2011) conducted a study on the productivity of total and partial labor in 38 countries up to 2005, of which 29 were developing countries and 9 were high-income countries. Their paper's results show that since 1990, structural changes have led to declining growth in Africa and Latin America. The difference in productivity performance in these countries compared to Asia is due to structural change patterns. In Asia, labor has shifted from low-productivity to high-productivity sectors, but the opposite has happened in Africa and Latin America. Both authors conducted the same study again in Africa in 2014, taking into account some changes.

John (2016), in his dissertation, examines the impact of trade on the components of productivity growth, i.e., within sectors and components of structural change during the years 1965-2006 in developed and developing countries. John uses a geographic-based endogenous variable for trade. The results show that increasing trade increases labor productivity. Countries that are free to trade are also able to import a variety of foreign goods that are not invented locally, and this causes the level of production to increase permanently as productivity increases in sectors such as production, but the innovation rate of new products does not change. Another result of this study was the positive effect of trade on each sector's productivity, which affects the growth of productivity.

Erumban et al. (2019), in an article entitled "Structural change and economic growth in India," examined the effect of structural change on productivity growth in the years 1980-2011. Their research indicates the positive effect of structural change on labor productivity growth because workers have been transferred to higher productivity sectors.

Komijani and Ghavidel (2006), in an article entitled "The role of trade liberalization on the labor market and employment and estimating the labor demand function in Iran," investigated the impact of trade liberalization on the structure of the Iranian labor market. Given the theoretical foundations of the labor market and the literature, they estimated the demand functions for skilled and unskilled labor, in the long-run and short-run, as well as with oil and without oil economy. In each of the estimation functions, the index of the 
degree of openness of the economy in the labor demand functions is included in the time-series literature method. These results showed that the Iranian labor demand function in the long-run has no effect on trade liberalization in the period under study (1971-2004). However, in the short run, the labor demand function, in most cases, has a positive effect on the degree of openness of the economy, and in the short run, the effect of liberalization is such that its role in the employment of skilled labor is greater than that of unskilled labor. The results also showed that in both skilled and unskilled labor, the effect of the degree of openness of the economy on the economy with oil in the short run is greater than the economy without oil.

Ahangari and Khorramzadeh (2012), in their study, examined the effects of structural changes in production, exports, and productivity on economic growth in the Iranian oil-dependent economy to determine whether the industrialization of Iran's economy strengthened the country's economic growth or not? Industrialization was through increasing the share of industry and mining in the gross domestic product (GDP) and total exports, as well as the increase in the productivity ratio of this sector to the agricultural sector. This research has been done using time series statistics from 1988 to 2008 and ARDL econometric method. Estimating two models of GDP and oil-free GDP shows that increasing the share of industry and mining in GDP has not had a significant effect on Iran's economic growth in the long run but has a negative effect on GDP and oil-free GDP in the short run. However, with a one-year break, it causes GDP growth. The variable coefficients of the sector's share in total exports show a negative relationship with GDP in the long run with a confidence level of 90 and 95\% in the short run with GDP. Finally, increasing the productivity ratio of industry and mining to agriculture in the long and short term causes GDP growth but has no significant effect on oil-free GDP. According to the results, it can be concluded that among the three structural variables in the paper, increasing the productivity ratio of industry and mining to agriculture in the short and long term has a positive effect on economic growth. However, structural changes in Iran's oil-based economy through the channel of increasing the share of industry and mining in GDP and total exports, contrary to industrialized countries' experience, have hurt economic growth.

Moshiri and Eltejaei (2015) have studied the long-term structural change trend in the Iranian economy, which is based on the Hodrick-Prescott filter. To do this, the status of structural variables in the periods before the first oil leap (years before 1973), the oil period (1973 to 1980), the period of revolution and war (1978 to 1988), the period of reconstruction (1989 to 1998) 
and the implementation period of the third development plan (1999 to 2004) has been analyzed. The results show that in the period before the leap in oil prices, all the structural variables discussed in the Iranian economy had trends similar to the newly industrialized countries, but in the oil, revolution, and war periods, due to various economic and political shocks, they underwent inappropriate changes. During the reconstruction and Third Plan periods, although some indicators improved relatively, compared to their level and trend in the first half of the 70s, as well as compared to the level and trend of the corresponding variables in the newly industrialized economies, they are still in such a bad situation.

Fetros and Rasouli (2016) studied the effect of structural changes and income distribution in Iran during the period 1981-2014. The multidimensional structural change index is extracted from the original structural variables using multivariate principal components analysis techniques. The model of the research is based on a Cobb-Douglas function. The model estimation method is based on convergent topics and Autoregressive Distributed Lag (ARDL). The results show that changes in economic structure have a positive and significant effect on income distribution.

According to studies, the most important study on the effects of globalization and structural change on Total Factor Productivity is the study of McMillan and Rodrik (2011). They have used the share of employment in each sector to examine structural change and have neglected other dimensions of structural change. In this research, an attempt is made to introduce a multidimensional index that includes all aspects of structural change, and then the effect of this index and trade liberalization on productivity is investigated.

\section{Model Specification}

This study's main hypothesis is a positive and significant effect of structural changes and trade liberalization on total factor productivity. Accordingly, the model framework is designed based on the literature in the three agriculture, industry, and service sectors.

The current paper model is based on the Ramsey model derived from Romer (2017).

On the demand side, the objective function is to maximize social welfare, which is optimized according to the household budget. 
$u=\int_{m=1}^{3} e^{-\rho t} v\left(c_{1} \cdot c_{2} \cdot c_{3}\right) d t \quad \quad \rho>0 . \quad c \geq 0$

$c$ is the level of consumption, and the utility function $v$ is concave, which provides Inada conditions.

On the supply side, the production function is considered with a constant return to scale, and the objective is to maximize production relative to the firm budget.

$\mathrm{Y}_{\mathrm{t}}=\mathrm{A} \cdot \mathrm{F}\left(\mathrm{K}_{\mathrm{t}}, \mathrm{L}_{\mathrm{t}}\right)$

The assumptions of this model are as follows:

$\mathrm{L}^{*}$ is the exogenous workforce growing at a rate of $\mathrm{V}$.

$\mathrm{K}^{*}$ is an endogenous capital stock.

$\mathrm{A}^{*}$ is the total productivity of the factors.

$\mathrm{n}^{*}$ is the share of employment in each sector, so:

$\mathrm{n}_{1}+\mathrm{n}_{2}+\mathrm{n}_{3}=1$

$\mathrm{k} *$ is the ratio of capital to labor, so:

$\mathrm{n}_{1} \mathrm{k}_{1}+\mathrm{n}_{2} \mathrm{k}_{2}+\mathrm{n}_{3} \mathrm{k}_{3}=\mathrm{K}$

* Suppose there is no unemployment, and the movement of factors of production is free.

According to the study by Kongsamut et al. (2001) and Ngai and Pissarides (2007), we assume that the product of section $i$ is only consumer goods, and section m produces capital and consumer goods. so:

$c_{i}=F^{i}\left(n_{i} k_{i} \cdot n_{i}\right)$

$\dot{k}=F^{m}\left(n_{m} k_{m} \cdot n_{m}\right)-c_{m}-(\delta+v) k$

$\delta>0$ and is equal to the depreciation rate. The production function $\mathrm{F}^{\mathrm{i}}($.) has a constant return to scale and $\mathrm{F}^{\mathrm{m}}$ (.) has a decreasing and positive return to inputs and provides these conditions. Factors $n_{i}$ and $k_{i}$ are allocated among 3 sections through static productivity conditions:

$\frac{v_{i}}{v_{m}}=\frac{F_{k}^{m}}{F_{k}^{i}}=\frac{F_{N}^{m}}{F_{N}^{i}} \quad \forall i$

$F_{N}^{i}$ and $F_{k}^{i}$ are the final output of labor and capital in sector i, respectively, according to which the rate of return on capital and labor is equal in all sectors. 
The allocation of production to consumption and capital through dynamic productivity conditions is as follows:

$-\frac{\dot{v}_{m}}{v_{m}}=F_{k}^{m}-(\delta+\rho+v)$

That the relevant condition is equal to:

$\lim _{t \rightarrow \infty} k \exp \left(-\int_{0}^{t}\left(F_{k}^{m}-\delta-v\right) d t\right)=0$

Given that the TFP growth rate varies across sectors, it is assumed that the production functions are the same in all sectors but have different TFP growth rates and TFP is the technology parameter for production in industry and is not TFP average for all segments. Accordingly:

$F^{i}=A_{i} F\left(n_{i} k_{i} \cdot n_{i}\right) ; \quad \frac{\dot{A}_{i}}{A_{i}}=\gamma_{i} ; \quad \forall i$

By dividing the sides of the production function by A.n:

$f(k) \equiv F(k .1)$

By removing the index i, equation (8) is equal to:

$F_{k}=A f_{k}$

$F_{N}=A\left[f(k)-k f^{\prime}(k)\right]$

Thus:

$\frac{F_{N}}{F_{k}}=\frac{f(k)}{f^{\prime}(k)-k}$

Also, A or TFP (Total Factor Productivity) is defined according to the literature presented in this study as follows:

$\mathrm{A}=\mathrm{F}$ (structural change, trade liberalization, institutions)

Structural change in the model is considered as a state in which the share of labor in at least one part changes over time, i.e., $0 \neq \dot{n}_{i}$.

The share of employment in sectors depends on the demand for labor in that sector:

$\frac{n_{i}}{n_{j}}=\frac{x_{i}}{x_{j}}$

The relative employment growth rate also depends on the difference between the TFP growth rates of the sectors: 
$\frac{\dot{n}_{i}}{n_{i}}-\frac{\dot{n}_{j}}{n_{j}}=\left(\gamma_{j}-\gamma_{i}\right)$

\section{Model Estimation}

To obtain the multidimensional index of structural changes from the 11 variables mentioned, the principal component method and EViews software were used. In principal component analysis, we suffice with the first component because the first component usually contains the most variance. The extracted results are given in Table (2):

Table 2

Principal Components Analysis

\begin{tabular}{ll}
\hline Variables & Eigenvalues \\
\hline Agricultural value-added to GDP & 0.35 \\
Industrial value-added to GDP & 0.35 \\
Services value-added to GDP & 0.35 \\
Agricultural employment & 0.35 \\
Industrial employment & 0.35 \\
Services employment & 0.35 \\
Export to gdp & 0.35 \\
Import to gdp & 0.35 \\
Urbanization & 0.35 \\
Birth & 0.35 \\
Morality & 0.35 \\
\hline
\end{tabular}

Source: Research Findings

According to the literature, the ARDL model has been used to investigate the effect of trade liberalization and structural changes on total factor productivity. The model studied in the current paper is based on the study of McMillan and Rodrik (2011) . Also, to study the effect of institutions on total factor productivity, six indicators of good governance and economic freedom index have been used. Out of the 256 estimated dynamic patterns, the model with the optimal lag according to the Schwarz-Bayesian criterion is presented below. 
$\operatorname{ARDL}(1,0,0,0,0,0,0,0,1)$

Productivity $=\mathrm{c}+\beta_{1}$ productivity $(-1)+\beta_{2}$ structure $+\beta_{3}$ voice $+\beta_{4}$ politic $+\beta_{5}$ freedom $+\beta_{6} \mathrm{D}+\beta_{7}$ copru $+\beta_{8}$ copru^ $2+\beta_{9}$ tropen $+\beta_{10}$ tropen(-1)

Table 3

ARDL Estimation

\begin{tabular}{|c|c|c|c|c|c|}
\hline Symbol & variable & coefficient & $\begin{array}{l}\text { Std. } \\
\text { Error }\end{array}$ & t-statistic & prob \\
\hline $\begin{array}{l}\text { productivity(- } \\
\text { 1) }\end{array}$ & Total productivity & 0.03 & 0.13 & 0.23 & 0.81 \\
\hline Structure & Structural change & 0.005 & 0.001 & 2.81 & 0.01 \\
\hline Voice & $\begin{array}{l}\text { Voice and } \\
\text { Accountability }\end{array}$ & 0.05 & 0.04 & 1.14 & 0.26 \\
\hline Politic & Political Stability & 0.14 & 0.03 & 4.56 & 0.0003 \\
\hline Freedom & $\begin{array}{l}\text { economic } \\
\text { freedom }\end{array}$ & 0.005 & 0.001 & 3.68 & 0.001 \\
\hline $\mathrm{D}$ & Dummy variable & -0.14 & 0.02 & -5.14 & 0.0001 \\
\hline Copru & \multirow{2}{*}{$\begin{array}{l}\text { Control } \\
\text { Corruption }\end{array}$} & 0.57 & 0.13 & 4.28 & 0.0005 \\
\hline $\mathrm{Copru}^{\wedge} 2$ & & 0.75 & 0.11 & 6.43 & 0.00 \\
\hline Tropen & \multirow{2}{*}{$\begin{array}{l}\text { Trade } \\
\text { liberalization }\end{array}$} & 0.32 & 0.13 & 2.47 & 0.02 \\
\hline tropen(-1) & & 0.49 & 0.11 & 4.10 & 0.0007 \\
\hline $\mathrm{C}$ & Constant & 0.75 & 0.16 & 4.61 & 0.0002 \\
\hline & & & $\begin{array}{l}\mathrm{R}^{2}= \\
0 / 89\end{array}$ & $\begin{array}{l}\text { Prob F = } \\
0.000002\end{array}$ & $\begin{array}{l}\text { Schwarz } \\
\text { criterion= } \\
-3.28\end{array}$ \\
\hline
\end{tabular}

Source: Research Findings

Based on the short-term dynamic pattern estimation results, F-statistic indicates that the whole regression is correct in the $99 \%$ confidence interval. The coefficient of determination $\mathrm{R}^{2}$ also indicates the high explanatory power of the model. Trade liberalization is significant at a $95 \%$ confidence interval and positively affects total factor productivity. As mentioned in the previous section, trade liberalization increases all factors' productivity due to competition, increased efficiency, efficient allocation of resources, use of economies of scale, expansion of domestic markets, expansion of initiative and innovation, and spread of technology. This result is consistent with the research conducted by Fernandes (2007), John (2016), Mustafa et al. (2017), Rahimi Boroujerdi (2005), Dehghanpour (2011).

Structural change is significant at a $99 \%$ confidence interval and increases the productivity of all factors in the short run. In Iran, during the period 19912018, resources have been reallocated to sectors with higher productivity, which has stimulated the demand for more innovation and a more efficient 
production process. This result is consistent with that of Szirmai (2009), Warburton (2012), McMillan et al. (2014), Erumban et al. (2019).

Among the indicators of good governance that have been used to show the quality of institutions, political stability and corruption control have a positive and significant effect on total factor productivity, and also the economic freedom index causes the growth of total factor productivity in the short term. Economic freedom is one of the important principles in assessing countries' economic development, which means leaving the way open to individuals in various fields, ownership, work and effort, production, and consumption. In economically free societies, the government allows labor, capital, and goods to move freely without coercion or restriction. Therefore, resources move to higher productivity activities and increase overall productivity.

The classical hypotheses regarding the estimation of the short-term dynamic model have been examined. According to Tables 4, 5, and 6, the residual has a normal distribution with homoscedasticity of the variances in the above model, and they are not auto-correlated.

Table 4

Normality test

\begin{tabular}{|l|l|}
\hline Kurtosis & 2.75 \\
\hline Probability & 0.65 \\
\hline
\end{tabular}

Source: Research Findings

In this test, the null hypothesis states that the error terms are abnormal, which is rejected according to the available statistics. As a result, the residuals have a normal distribution.

Table 5

LM Test

\begin{tabular}{|l|l|}
\hline Prob F(1,16) & $0 / 07$ \\
\hline Prob chi-square(1) & $0 / 02$ \\
\hline
\end{tabular}

Source: Research Findings

In this test, the null hypothesis is the presence of autocorrelation in disturbance terms, which is rejected according to the F statistic. There is no autocorrelation in disturbance terms. 
Table 6

ARCH Test

\begin{tabular}{|l|l|}
\hline Prob F $(1,25)$ & $0 / 68$ \\
\hline Prob Chi-Square(1) & $0 / 67$ \\
\hline
\end{tabular}

Source: Research Findings

In this test, the null hypothesis is the presence of homoscedasticity that is rejected, and there is homoscedasticity of the variances.

Estimated parameters may also change over time, and unstable parameters may lead to inaccurate diagnosis. Therefore, the structural stability test seems necessary. Diagnostic tests are used to determine model stability and structural stability.

The current paper has used CUSUM diagram for model stability. If the statistical graph intersects one of the sidelines at the 5\% level, the model will not be stable. The following diagram shows the absence of structural break in this period.

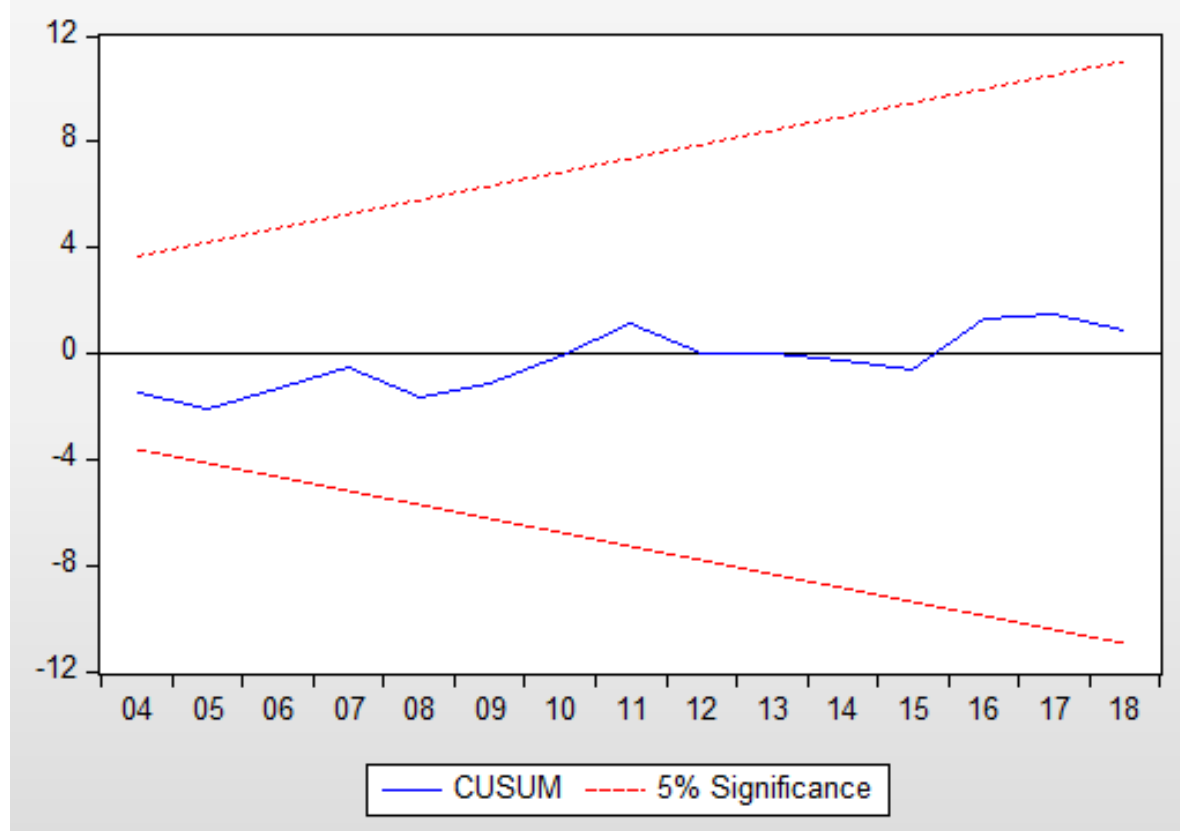

Figure 1. Cusum test

Source: Research Findings 
To examine the presence of a long-run relationship, it is necessary to test the correlation between the model variables. The condition for the variables to be stocked is that the sum of the coefficients of the intermittent dependent variables that appear as the explanatory variable is less than one. Therefore, to ensure the above result, the following hypothesis should be tested:

$\left\{\begin{array}{l}H_{0}: \sum_{i=1}^{S} \hat{\alpha_{i}}-1 \geq 0 \\ H_{1}: \sum_{i=1}^{S} \hat{\alpha_{i}}-1<0\end{array}\right.$

The used test statistic in term of Null Hypothesis is the absence of a longrun equilibrium relationship between the model variables of type $t$, and its value is calculated from the following formula:

$\tau=\frac{\sum_{i=1}^{S} \alpha_{i}-1}{\sum_{i=1}^{S} S E \alpha_{i}}$

Then the above computational statistics should be compared with the values of the Banerjee-Dolado-Master table.

In this study, because some variables are at the durability level and some are durable with one differentiation, we cannot use the Banerjee-DoladoMaster statistic to check for the presence or absence of a long-term relationship. We must use the Bounds test to check for a long-term relationship.

The Null Hypothesis in this test is the absence of a long-term relationship.

\section{Table 7}

ARDL Bounds Test

\begin{tabular}{lll}
\hline Test Statistic & Value & $\mathbf{k}$ \\
\hline F-statistic & 0.952036 & 8 \\
\hline Source: Research Findings & &
\end{tabular}

\section{Table 8}

Critical Value Bounds

\begin{tabular}{lll}
\hline Significance & I0 Bound & I1 Bound \\
\hline $10 \%$ & 1.85 & 2.85 \\
$5 \%$ & 2.11 & 3.15 \\
$2.5 \%$ & 2.33 & 3.42 \\
$1 \%$ & 2.62 & 3.77 \\
\hline
\end{tabular}

Source: Research Findings 
The estimated F statistic value is lower than the critical value of the lower bound, and the hypothesis $\mathrm{H}_{0}$ is not rejected. There is no long-term relationship between the explanatory variables of the model and the productivity of all factors.

\section{Conclusion}

Given the growing importance of globalization and the fact that structural change in developing countries is necessary to raise living standards and reduce poverty, the purpose of this study is to investigate the effect of trade liberalization and structural change on interest rates of total factors. Trade liberalization may be a method of internal restructuring that can affect the production process's inputs and output. With the advent of specialization, resources are shifting to the most productive direction, increasing production and revenue. With increasing openness and foreign competition, manufacturers are forced to look for more efficient production methods. Increased competition in imports has forced manufacturing industries in Latin America and elsewhere to become more efficient by rationalizing their operations. Typically, low-yield firms are out of the industry, and the remaining firms have adjusted the extra labor force and bridged the gap with the help of advanced technology, thus increasing overall returns in the economy (Pavcnik, 2002). In developing economies, workers may be driven to even less productive activities. In other words, the rationalization of manufacturing industries may come at the cost of stunting structural changes. In the period under study, trade liberalization and structural changes in Iran have increased all factors' productivity.

\section{References}

Aiginger, K. (2001). Speed of Change and Growth of Manufacturing. Structural Change and Economic Growth, M, Peneder et. al., Structural Change and Economic Growth, WIFO, Vienna.

Ahangari, A. and Khoramzadeh, A. (2012). Investigation the Effect of Structural Changes on GDP in Iran: with emphasis on product, Export and Labour Productivity, Quarterly Journal of Quantitative Economics, Volume 3, Number 1, 11-71. (In Persian).

Aizenman, J., Lee, M. \& D. Park. (2012). The Relationship between Structural Change and Inequality: A Conceptual Overview With Special Reference to Developing Asia. ADB Institute.

Lindley, J. K., Brullhart, M., \& Elliott, R. (2005). Intra-industry Trade and Labour Market Adjustment: A Reassessment Using Data on Individual Workers (No. 2005005). 
Chenery, H. B., Srinivasan, T. N., Schultz, T. P., Behrman, J. R., Strauss, J., Rodrik, D., \& Rosenzweig, M. R. (Eds.). (1988). Handbook of development economics (Vol. 4). Elsevier.

Chenery, H., Syrquin, M., \& Xinhua, L. (1988). The Development Style: 19501970. Li Xinhua et al. Beijing: Economic Science Press (In Chinese).

Choudhri, E. \& D. S. Hakura (2000). International Trade and Productivity Growth: Exploring the Sectoral Effects for Developing Countries. International Monetary Fund Staff Papers, 47(1), 30-53.

Clark, C. (1940). The Conditions of Economic Progress. London: Macmillan.

Dehghanpour, F. (2011). The Effect of Trade Liberalization on the Total Factor Productivity (1993-2007). Master Thesis in Economics, Shahid Ashrafi Isfahani Institute (In Persian).

Erumban, A. A., Das, D. K., Aggarwal, S. \& Das, P. C. (2019). Structural Change and Economic Growth in India. Structural Change and Economic Dynamics, 51, 186202.

Fernandes, A. M. (2007). Trade Policy, Trade Volumes and Plant-Level Productivity in Colombian Manufacturing Industries. Journal of International Economics 71(1): 52-71.

Fetros, M. H., \& Rasouli, M. (2016). The Effect of Structural Changes on Income Inequality in Iran. Al-Zahra University Economic Policy Quarterly, Fourth Year, No. 10, pp. 9-42. (In Persian).

Fischer, S. (2003). Globalization and its Challenges. American Economic Review, 93(2), 1-30.

Harris, J. R., \& Todaro, M. P. (1970). Migration, Unemployment and Development: A Two-Sector Analysis. The American Economic Review, 60(1), 126-142

Herzer, D. (2005). Manufacturing Export, Mining Export and Growth: Cointegration and Causality Analysis for Chile. German Institute for Economic Research.

John, A. A. (2016). Empirical Studies in Trade, Structural Change and Growth (Doctoral Dissertation, University of Nottingham).

Kelbore, Z. G. (2014). Multidimensional Structural Transformation Index: A New Measure of Development. MPRA Paper No. 62920

Komijani, A., \& Ghavidel S. (2006). The Role of Trade Liberalization in Labor and Employment Market and Estimation of Labor Demand Function in Iran .Journal of Economic Research, No. 20. (In Persian).

Kongsamut, P., Rebelo, S. \& Xie, D. (2001). Beyond Balanced Growth. The Review of Economic Studies, 68(4), 869-882.

Krueger, A. (2004). Expanding Trade and Unleashing Growth: The Prospects for Lasting Poverty Reduction. International Monetary Fund Seminar on Trade and Regional Integration.

Kuznets, S. (1971). Modern Economic Growth: Findings and Reflections. Nobel Prize in Economics documents (1971-2).

Lewis, W. A. (1954). Economic Development with unlimited supplies of labor. Manchester School of Economic and Social Studies. 
McMillan, M. S. \& D. Rodrik (2011). Globalization, Structural Change and Productivity Growth. National Bureau of Economic Research Working Paper Series 17143.

McMillan, M. S., D. Rodrik. \& verduzco-gallo (2014). Globalization, Structural Change and Productivity Growth, with an Update on Africa. World Development, vol. 63. Pp. 11-32.

Moshiri, S. \& Eltejaei, E. (2015). A Comparative Study of the Long-Term Trend of Structural Changes in the Iranian Economy in Comparison with Newly Industrialized Economies (In Comparison with Newly-Industrialized Economies). Comparative Economics, Institute of Humanities and Cultural Studies, Second Year, Journal of Iranian Economic Issues, No. 1. 149-194. (In Persian).

Mustafa G, Rizov M, \& Kernohan D, (2017). Growth, Human Development and Trade: The Asian Experience. Economic Modelling, No.61, pp.93-101

Ngai, R.L., \& Pissarides, C.A. (2007). Structural Change in a Multisector Model of Growth, American Economic Review, 97(1): 429-443.

Pavcnik, N. (2002). Trade Liberalization, Exit, and Productivity Improvements: Evidence from Chilean Plants. The Review of Economic Studies 69(1): 245-276.

Rahimi Boroujerdi, A. (2006). The Relationship between Economic Growth and Trade in Industry Sector. Journal of Knowledge and Development, No. 18. pp. 179-195. (In Persian)

Rahimi Boroujerdi, A. (2010). Globalization. University of Tehran Press. (In Persian). Romer, D. (2017). Advanced Macroeconomics. Translated by Dr. Mansour Khalili Iraqi and Dr. Ali Souri. Noor Elm Publications. (In Persian).

Syrquin, M. (1998). Modern Economic (Endogenous) Growth and Development. In New theories in growth and development (pp. 155-174). Palgrave Macmillan, London.

Syrquin, M. (1988). Patterns of Structural Change. Handbook of development economics, 1, 203-273.

Syrquin, M. (1986). Growth and structural change in Latin America since 1960: a comparative analysis. Economic Development and Cultural Change, 34(3), 433454.

Szirmai, A. (2009, October). Industrialisation as an Engine of Growth in Developing Countries. Georgia Institute of Technology.

Timmer, B. C. P., \& Akkus, S. (2008). The Structural Transformation as a Pathway out of Poverty: Analytics, Empirics and Politics. Center for Global Development, (150).

Warburton, C. E.S. (2012). Globalization and Structural Change in the US Manufacturing Sector, 1987-2010. Econometrics and International Development. Vol. 12-1. 